\title{
An Empirical Investigation of Service Quality, Tourist Satisfaction and Future Behavioral Intentions among Domestic Local Tourist at Borobudur Temple
}

\author{
Ivyanno U. Canny
}

\begin{abstract}
Firstly, the purpose of this paper attempted to investigate the relationship between the five dimensions of service quality on tourist satisfaction. Since, tourist satisfaction is considered to be a great predictor for future behavioral intentions in many nature of tourism destinations, the second purpose of this study was to investigate the relationship between tourist satisfactions on future behavioral intentions. This study was examined using SERVQUAL model and analyzed with multiple regression analysis. This field research was conducted on 28-31 May 2012 at the Borobudur temple, Magelang, Central Java Indonesia. The model was tested using data collected from 200 domestic local tourists. The findings of this study showed that service quality had significant positive relationship with tourist satisfaction. While the study was revealed that positive relationship also occurs between tourist satisfaction on future behavioral intentions.
\end{abstract}

Index Terms-Domestic local tourist, future behavioral intentions, tourist satisfaction, service quality, servqual.

\section{INTRODUCTION}

Travel and tourism industry continues to be one of the largest industries in the world. The total impact of the industry in 2011, contributed 9\% of global Gross Domestic Product (GDP), or a value of over US\$6 trillion, and contributed for 255 million jobs in the world [1]. Along with the world's travel and tourism development, Indonesia tourism becomes one of the most important components to the national economy, as well as an important source of foreign exchange revenues for the country. Indonesia is a country with varieties of cultural, natural and historical resources, which offer a wide range of tourism destinations and attractions. Therefore, its not surprising that Indonesia tourism become the third largest contributor as non-oil and gas for the national income, after timber and textile [2]. Thus, Indonesia tourism was ranked $13^{\text {th }}$ in the regional ranking and $74^{\text {th }}$ of 196 countries in the world [3].

Indonesia is one of the Southeast Asia countries (ASEAN) that are concerned for the preservation of cultural heritage and sustainable tourism. The cultural and heritage tourism sector is currently become one of the key destination attraction in fascinating a large numbers both for foreign and domestic local tourists arrivals in Indonesia. There were seven sites across Indonesia that was acknowledged by UNESCO and the world as a world heritage sites, and one of the most widely known is Borobudur temple. Borobudur

Manuscript received October 19, 2012; revised March 2, 2013.

Ivyanno U. Canny is with School of Business Administration, Faculty of Business Administration and Humanities, Swiss German University, BSD City, Tangerang - Indonesia (e-mail: ivyanno.canny@gmail.com) temple was one of the fundamental manifestations of Indonesian cultural heritage. It has its own uniqueness, which combines aspects of culture and religion that are very solid in Indonesia. In 2011, Indonesia has attracted approximately of 7 million foreign tourists and 6 million domestic local tourists to visit Indonesia [4], [5] and one-third of the domestic local tourist arrivals in Indonesia were visiting Borobudur temple in 2011[6]. The enormous number of domestic local tourist arrivals in Borobudur temple, triggered Borobudur temple authority agency should be able to dealing with the domestic local tourist demand regarding the decent provided service quality in the destination. Considering, the role of domestic local tourist cannot be disregarded, since domestic local tourists spending has contributed for $79.1 \%$ of direct travel and tourism GDP in 2011 compared with $20.9 \%$ of foreign tourists spending [1]. Therefore, the importance of measuring service quality and satisfaction are to predicting consumer behavior of domestic local tourists in Indonesia. Hence, investigating consumer behavior through behavioral intentions can provide a better understanding of customer retention in tourism destination [7], particularly for management of cultural heritage destination.

Numerous recent studies on the linkage between service quality, tourist satisfaction and future behavioral intentions are well conducted in the scope of tourism literature [8], [9], [10]. However, until now research has not been fully subjected to conceptual and empirical investigation in cultural heritage tourism context especially in Indonesia cultural heritage site. The purpose of this study, then, was to investigate the positive relationship between the five dimensions of service quality on tourist satisfaction and to investigate the positive relationship of tourist satisfaction on future behavioral intentions.

In particular, the findings of this study will provide a road map guideline for Borobudur temple authority agency to be able to retain the quality of service that is considered very satisfactory by the tourists and improve the quality of services that are considered unsatisfactory by the tourists.

\section{THEORETICAL BACKGROUND AND HyPOTHESES}

\section{A. Service Quality and Tourist Satisfaction}

In the highly competitive tourism industry, service quality has been identified as the key factors in maintain destination competitiveness. Furthermore, decent service quality is not only intended to satisfying the tourists but it also improve the destination image, differentiate the destination from others and construct a loyal tourist to perform a certain post-visit behavior such as revisit and positive word of mouth. Despite 
of many definitions of service quality, commonly the various definitions of service quality have the same outline. Service quality is defined as consumers' subjective judgment of a service provided by the provider, according to the gap between customers expectation and realistic perception of the service [11]-[15].

Research on service quality becomes a major concern in tourism and hospitality industry, since these industries basically dealing with people-oriented service delivery [16]. The most popular and widely used instruments that have been conducted by many researchers to analyze the concepts of service quality and customer satisfaction in the service industry were SERVQUAL model. SERVQUAL is a model of service quality, which was developed by Parasuraman for the first time. SERVQUAL is multiple-item scale for measuring the difference between consumers' expectations and perceptions of service [17]. Originally, the SERVQUAL dimensions was introduced into 10 dimensions [17], which are tangible, reliability, responsiveness, competence, courtesy, credibility, security, access, communication and understanding the customers. Afterward, the original ten dimensions of SERVQUAL were regroup into five dimensions or also known as RATER, including reliability (ability to perform the promised service dependably and accurately), assurance (employees' knowledge and courtesy and their ability to inspire trust and confidence), tangible (appearance of physical facilities, equipment, personnel and communication materials), empathy (caring, individualized attention given to customers) and responsiveness (willingness to help customers and provide prompt service) [15], [18]. In tourism industry, quality of consistent delivery and visitor services according to expected standards is become one of the major challenges for the destination management will be facing in the following years as it is a crucial condition for destinations' success in the competitive and emerging tourism industry.

On other hand, service quality has become a great predictor to outcomes, such as customer satisfaction [19]. Although, there is no specific definition on satisfaction, but the most acceptable definition of satisfaction was "an evaluative, affective or emotional response" [20]. In destination marketing, tourist satisfaction is considered to be very important, as it is very influential in the choice of destinations, the consumption of products and services, and the tourists' decision to return [21]. Bowen and Clarke [22] adding that tourist satisfaction are acknowledged as one of the key judgment that tourists use to measure a tourism service. Hence, measurement between service qualities with tourist satisfactions allows destination management to fully understand how to provide the best possible service quality to satisfied tourists.

In recent years, several researchers have been investigated the relationship between service quality and tourist satisfaction in tourism destinations. The connections between service quality and tourist satisfaction are arguably the most widely studied relationships in tourism literature. The growing interest of researchers to the issue between service quality and tourist satisfaction its widely accepted that service quality has a direct effect on tourist satisfaction [9], [12], [23]-[25]. Moreover, it has been specified the primary objective within tourism providers for investing exertion in evaluating and improving quality of performance and seeking to enhance level of tourist satisfaction [23], [26]. The first hypothesis, therefore, would be:

Hypothesis 1. There is a significant relationship between the five dimensions of service quality on tourist satisfaction

\section{B. Tourist Satisfaction and Future Behavioral Intentions}

One definition of satisfaction that is frequently cited is a particular feeling felt by customers, which is achieved by comparing perceived performance with customer's expectations on particular product or services [27]. As noted by several researchers, satisfaction was known as a function of consumer perceptions. Meanwhile, the perception of each individual is very difficult to be measured in tourism context, due to the nature of the product [28].

In the tourism literature it has generally accepted that when the tourists feeling satisfied on services, products, and other resources, which provided by tourism destinations it could lead repeat, visits same as positive word of mouth effects to such as relatives and/or colleagues [8], [10], [23], [29], [30]. Hence, recommendations about the destinations to other are also one of the most often required types of information for people interested in traveling [31]. Whereas, several researchers and practitioners viewed that the relationship of tourist satisfaction on future behavioral intentions as an important research topic, since customers' satisfaction and dissatisfaction considered become the driving force that shapes the customers' attitudes and behavior in the future [8], [22], [24]. Future behavioral intentions are explained as conative loyalty, which is part of the four stage of loyalty model according to Oliver [32]. Conative loyalty was described as customers' loyalty that accompanied by a desire to intend an action [33].

Several studies on tourism research successfully generate the numerous proxies of future behavioral intentions. Cole and Illum [24] used say positive things about the destination and revisit the destination in the future while assessing the influence of service quality on behavioral intentions in rural heritage festival in Missouri, U.S. However, another studies established the applicable proxies of future behavioral intentions, includes word-of-mouth and revisit intentions [18], [29], [34]. Additionally, research on the case study of Chinese tourist in Korea [35] applied revisit, say positive thing and recommend destinations to other as the proxies of future behavioral intention. From these statements is derived Hypothesis 2:

Hypothesis 2. There is a significant relationship between the tourist satisfactions on tourist future behavioral intentions

\section{RESEARCH MODEL}

The research model, which guided the development of the study's hypotheses, can be seen in Fig. 1. The research model investigates the relationship among service quality, tourist satisfaction and future behavioral intentions.

The theory of service quality refers to SERVQUAL model which measuring consumers perceptions of service quality with a multiple-scale items or widely known as the SERVQUAL five dimensions (reliability, ability, tangible, 
empathy and responsiveness). While the tourist satisfaction was refers to the theory of Expectancy Disconfirmation Paradigm (EDP), which stated that satisfaction is a result of customers' discrepancies between prior expectations and actual performance.

Moreover, the proxies of future behavioral intentions were derived from theory called four stages of loyalty, which were cognitive, affective, conative and action loyalty. Future behavioral intentions was recognized as a type of conative loyalty which defined as customers' loyalty that accompanied by a desire to intend an action - in this study as intention to revisit, say positive thing and recommend the destination to others.

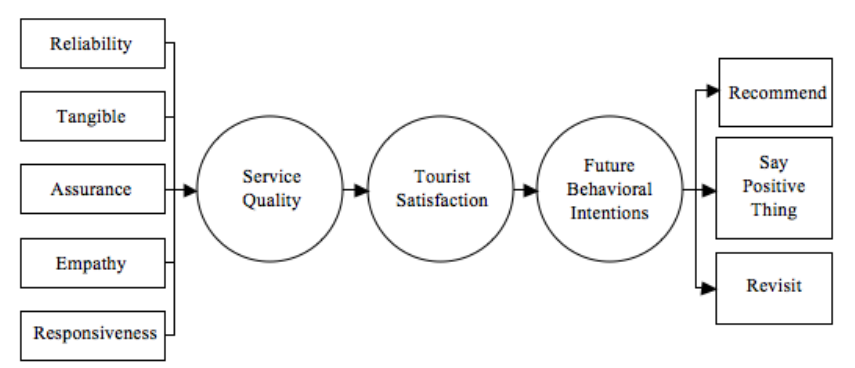

Fig. 1. Research model

\section{RESEARCH METHODS}

\section{A. Research Sample}

This study employs 200 domestic local tourists who currently visited Borobudur Temple on 28-31 May 2012. The distributions area of questionnaires was in the exit gate and respondent asked to fill out questionnaire at a most convenient place.

A frequency analysis was employed to survey the distribution of various variables based on demographic profiles, such as gender, age, education level, average monthly expenditures and occupation (Table I). 53\% of the respondents were male. $24 \%$ and $28 \%$ of the respondents were between the ages of 21-30 and 31-40 years old. 59\% of the respondents were college graduates. With regard of occupational status, $28.5 \%$ were students and $20 \%$ of the respondents were government officer and housewife. Respectively, $45.5 \%$ of the respondents had an average monthly expenditure of 1-2 million ( $\mathrm{Rp}$ ).

TABLE I: DEMOGRAPHIC CHARACTERISTICS OF RESPONDENTS

\begin{tabular}{lll}
\hline \hline Characteristics & Frequency & $\begin{array}{l}\text { Percentage } \\
(\mathrm{N}=200)\end{array}$ \\
\hline Gender & & \\
Male & 106 & 53 \\
Female & 94 & 47 \\
Total & 200 & 100 \\
Age & & \\
$17-20$ & 26 & 13 \\
$21-30$ & 48 & 24 \\
$31-40$ & 56 & 28 \\
$41-50$ & 47 & 23.5 \\
Above 50 & 23 & 11.5 \\
Total & 200 & 100 \\
Education & & \\
Elementary school & 10 & 5 \\
Junior high school & 9 & 4.5 \\
High school & 63 & 31.5 \\
College & 118 & 59 \\
Total & 200 & 100 \\
\hline \hline
\end{tabular}

\begin{tabular}{lll}
\hline \hline Characteristics & Frequency & $\begin{array}{l}\text { Percentage } \\
(\mathrm{N}=200)\end{array}$ \\
\hline Occupation & 57 & \\
$\quad$ Student & 40 & 28.5 \\
Government officer & 24 & 20 \\
Professional & 33 & 12 \\
Entrepreneur & 40 & 16.5 \\
Housewife & 6 & 20 \\
Others & 200 & 3 \\
Total & & 100 \\
Average Monthly Expenditures $($ Rp) & 91 & \\
1-2 million & 86 & 45.5 \\
$2-5$ million & 23 & 43 \\
$5-10$ million & 200 & 11.5 \\
Total & & 100 \\
\hline \hline
\end{tabular}

\section{B. Measures}

The measurements were adapted and modified from the theories has been discussed in the theoretical background above. The measurements were included the following 26 items (Table II): service quality (20 questions), tourist satisfaction (3 questions) and future behavior intentions (3 questions). All the items were scored with five-point Likert scale regarding to whether respondents agree or disagree with each statement items.

TABLE II: ITEMS FOR VARIABLES

\begin{tabular}{|c|c|}
\hline Variables & Items \\
\hline \multirow{6}{*}{$\begin{array}{l}\text { Service Quality } \\
\text { (SQ) }\end{array}$} & Reliability \\
\hline & $\begin{array}{l}\text { Borobudur temple authority agency management was } \\
\text { reliable in creating a sense comfort for you (SQ1) }\end{array}$ \\
\hline & $\begin{array}{l}\text { Management provides visiting hours that suit your needs and } \\
\text { time availability (SQ2) }\end{array}$ \\
\hline & $\begin{array}{l}\text { Borobudur temple employees have promptness and } \\
\text { hospitality in serving you (SQ3) }\end{array}$ \\
\hline & $\begin{array}{l}\text { Borobudur temple authority agency management can } \\
\text { manage well the street vendors, kiosks and souvenir stalls } \\
\text { for more orderly selling around Borobudur temple area } \\
\text { (SQ4) }\end{array}$ \\
\hline & Assurance \\
\hline
\end{tabular}

Borobudur temple authority agency management provide information and directions that are easily understood by you (SQ5)

You feel comfortable and secure during your visit in the Borobudur temple (SQ6)

Borobudur temple employees always show politeness, friendliness and helpfulness to you (SQ7)

You get in-depth explanation from knowledgeable and experienced tour guides in Borobudur temple (SQ8)

Tangible

Borobudur temple's cleanness and well manage become the most attractive one (SQ9)

The environment around Borobudur temple is clean and neat (SQ10)

Borobudur temple employees dress professionally and neat (SQ11)

Public facilities that are provided by Borobudur temple authority agency management is well managed (i.e. rest room, parking lot, rest area etc.) (SQ12)

Empathy

Borobudur temple employees pay attention to the tourists needs (SQ13)

You get a polite and friendly service from the Borobudur temple employees (SQ14)

Borobudur temple employees are seriously in helping and satisfy you (SQ15)

When you ask about the public facilities location that you need immediately, Borobudur temple employees provide clear direction to you (i.e. rest room, prayer room, information center) (SQ16)

Responsiveness

Borobudur temple authority agency management are always 


\begin{tabular}{ll}
\hline \hline Variables & Items \\
\hline & $\begin{array}{l}\text { ready and eager to serve you (SQ17) } \\
\text { Borobudur temple employees were never too busy to } \\
\text { respond and help you quickly (SQ18) } \\
\text { You get the best possible service from Borobudur temple } \\
\text { employees (SQ19) } \\
\text { You no longer queue at the entrance gate, because the ticket } \\
\text { admission office deftly and swiftly address the line of } \\
\text { visitors at Borobudur temple (SQ20) }\end{array}$ \\
& $\begin{array}{l}\text { I am satisfied with my visit to Borobudur temple (TS1) } \\
\text { I have enjoyed my visit to Borobudur temple (TS2) }\end{array}$ \\
Satisfaction (TS) & $\begin{array}{l}\text { I am positive about revisiting Borobudur temple in the future } \\
\text { (TS3) }\end{array}$ \\
Future & $\begin{array}{l}\text { I will recommend Borobudur temple to others (FB1) } \\
\text { I will say something positive about my experience during } \\
\text { my visit in Borobudur temple to others (FB2) }\end{array}$ \\
Intentions (FB) & $\begin{array}{l}\text { I will return to Yogjakarta and revisit Borobudur temple in } \\
\text { the future (FB3) }\end{array}$ \\
\hline \hline
\end{tabular}

\section{Data ANALYsis AND Results}

\section{A. Validity and Reliability Test}

This study employed the analysis of Cronbach alpha coefficients using SPSS 20 to analyze the reliability of scales. All scales were proven sufficient reliability as they exceed regarding the reliability guidelines of 0.6 [36]. Therefore, all measuring factors had a high consistency and reliability of scales (See Table 3).

To evaluate the validity of questions for each questions, factor analysis were conducted. With a sample of 200 respondents, factor loadings in the range of 0.40 or greater are considered practically significant [37] (See Table III).

\section{TABLE III: VARIABLES RELIABILITY AND VALIDITY MEASURES}

\begin{tabular}{|c|c|c|c|}
\hline Variables & Items & Loadings & Cronbach $\alpha$ \\
\hline Service Quality & $\begin{array}{l}\text { SQ1 } \\
\text { SQ2 } \\
\text { SQ3 } \\
\text { SQ4 } \\
\text { SQ5 } \\
\text { SQ6 } \\
\text { SQ7 } \\
\text { SQ8 } \\
\text { SQ9 } \\
\text { SQ10 } \\
\text { SQ11 } \\
\text { SQ12 } \\
\text { SQ13 } \\
\text { SQ14 } \\
\text { SQ15 } \\
\text { SQ16 } \\
\text { SQ17 } \\
\text { SQ18 } \\
\text { SQ19 } \\
\text { SQ20 }\end{array}$ & $\begin{array}{l}0,678 \\
0,728 \\
0,848 \\
0,833 \\
0,891 \\
0,842 \\
0,813 \\
0,824 \\
0,831 \\
0,842 \\
0,873 \\
0,870 \\
0,853 \\
0,868 \\
0,838 \\
0,801 \\
0,887 \\
0,838 \\
0,847 \\
0,880\end{array}$ & 0,882 \\
\hline Tourist Satisfaction & $\begin{array}{l}\text { TS1 } \\
\text { TS2 } \\
\text { TS3 }\end{array}$ & $\begin{array}{l}0,685 \\
0,689 \\
0,798\end{array}$ & 0,722 \\
\hline $\begin{array}{l}\text { Future Behavioral } \\
\text { Intentions }\end{array}$ & $\begin{array}{l}\text { FB1 } \\
\text { FB2 } \\
\text { FB3 }\end{array}$ & $\begin{array}{l}0,816 \\
0,790 \\
0,784\end{array}$ & 0,758 \\
\hline
\end{tabular}

B. Test of Research Hypotheses

The first objective of this study was focused on testing the relationship between the five dimensions of service quality as the independent variable on the dependent variable, which is tourist satisfaction using determination coefficient. According to the results of Hypothesis 1, the overall model was significant at 0.000 or the $p$-value $<0.05$. The adjusted $R$ square is equal to 0.323 , which indicates that the five dimensions of service quality has a significant relationship on tourist satisfaction by $0.323(32.3 \%)$, where the remaining $0.677(67.7 \%)$ of changes were identified by other factors, which not mentioned in this study. Thus, the first hypothesis, which stated that there is a significant relationship between the five dimensions of service quality on tourist satisfaction, is accepted. The test results of the first hypothesis are shown in Table IV and V.

TABLE IV: REGRESSION RESULTS

\begin{tabular}{ccccl}
\hline \hline Model & $\mathrm{R}$ & R Square & $\begin{array}{l}\text { Adjusted R } \\
\text { Square }\end{array}$ & $\begin{array}{l}\text { Std Error of } \\
\text { Estimate }\end{array}$ \\
\hline 1 & $.583^{\mathrm{a}}$ & .340 & .323 & 1.45550 \\
\hline \hline $\begin{array}{l}\text { a. Predictors: (Constant), total reliability, total assurance, total tangible, total } \\
\text { empathy, total responsiveness }\end{array}$
\end{tabular}

TABLE V: ANOVA RESULTS

\begin{tabular}{llllll}
\multicolumn{5}{c}{ ANOVA $^{\mathrm{a}}$} \\
\hline \hline Model & $\begin{array}{l}\text { Sum of } \\
\text { Squares }\end{array}$ & df & $\begin{array}{l}\text { Mean } \\
\text { Square }\end{array}$ & F & Sig. \\
\hline Regression & 211.968 & 5 & 42.394 & 20.011 & $.000^{\mathrm{b}}$ \\
Residual & 410.987 & 194 & 2.118 & & \\
Total & 622.955 & 199 & & & \\
\hline
\end{tabular}

a. Dependent Variable: total satisfaction

b. Predictors: (Constant), total reliability, total assurance, total tangible, total empathy, total responsiveness

Furthermore, this study performed $t$ test for each SERVQUAL dimensions separately to discover which dimensions that becomes the most influential on tourist satisfaction. The result on Table VI shows that, tangible was recognized as the most influencing SERVQUAL dimension that influence tourist satisfaction, since the result of its Beta was the highest among other dimensions. Tangible has a value of 0.258 , followed with the second highest which was assurance (0.202), reliability (0.164), empathy (0.139) and finally, responsiveness was recognized as the least important SERVQUAL dimension that influence on tourist satisfaction, since the result of its Beta was the lowest among other dimensions and has a value of 0.084 .

TABLE VI: T-TEST RESULTS

\begin{tabular}{llll}
\hline \multicolumn{4}{c}{ TABLE VI: T-TEST RESULTS } \\
\hline Model & Beta & t-statistic & Sig. \\
\hline Reliability $\rightarrow$ Tourist Satisfaction & 0.164 & 1.947 & 0.045 \\
Assurance $\rightarrow$ Tourist Satisfaction & 0.202 & 2.495 & 0.013 \\
Tangible $\rightarrow$ Tourist Satisfaction & 0.258 & 3.597 & 0.000 \\
Empathy $\rightarrow$ Tourist Satisfaction & 0.139 & 1.832 & 0.168 \\
Responsiveness $\rightarrow$ Tourist Satisfaction & 0.084 & 1.091 & 0.277 \\
\hline \hline
\end{tabular}

Second, this study was using determination coefficient to investigate the relationship of tourist satisfaction on future behavioral intentions. According to the results of Hypothesis 
2, the p-value of the overall model was significant at p-value $<0.05$. Moreover, the relationship of tourist satisfaction on behavioral intentions is equal to $0.564(56.4 \%)$. The result indicates that if tourist satisfaction increased by one unit of value, then it will increase the future behavioral intentions of 0.564 . The test results of the second hypothesis are shown in Table VII below.

TABLE VII: T-TEST RESULTS

\begin{tabular}{|c|c|c|c|c|}
\hline \multicolumn{5}{|c|}{ Coefficients $^{\mathrm{a}}$} \\
\hline Model & & $\begin{array}{c}\text { Standardized } \\
\text { Coefficients } \\
\text { (Beta) }\end{array}$ & $\mathrm{t}$ & Sig. \\
\hline \multirow[b]{2}{*}{1} & (Constant) & & 8.073 & .000 \\
\hline & $\begin{array}{l}\text { Tourist } \\
\text { Satisfaction }\end{array}$ & .564 & 9.601 & .000 \\
\hline
\end{tabular}

a. Dependent Variable: future behavioral intentions

\section{CONCLUSIONS AND IMPLICATIONS}

According to the results of regression analysis made for the investigation of the relationship among service quality on tourist satisfaction of local domestic tourist in Borobudur Temple, it is found that service quality has a weak relationship on tourist satisfaction, since its only explained on tourist satisfaction by $32.3 \%$. In particular responsiveness dimension (0.277) was revealed as the least influencing dimensions since its rate was below from tourist expectations. This indicates that tourist felt that Borobudur temple employees are lack of willingness and readiness to help and provide prompt service according to what tourists expected. In contrast, tangible dimension (0.000) was revealed as the most influencing dimension. Tourist is highly satisfied with the Borobudur temple's cleanness and tidiness, which become the main important factors in the destination for them. However, the results of this study in contrast with the tourism studies, which also conducted SERVQUAL model who emphasized "tangible" as the least influencing dimensions for tourists [13], [26].

Since achieving tourist satisfaction is become one of the important objectives for most tourism service businesses and organizations today, increasing tourist satisfaction is believed will generate more profits and lowering marketing expenditures. Findings of this study reveled that tourist satisfaction has significantly effect on future behavioral intentions (56.4\%). Accordingly, the higher rate of tourist satisfaction with the service quality, the higher possibility to perform future behavioral intentions, such as recommend, say positive thing and revisit the destination.

Results of this study suggest that, Borobudur temple authority agency should focus on evaluating service quality in Borobudur temple, by conducting a periodic post-evaluation of each service quality factors, which considered still far from tourists' needs and expectations. The goal for improving service quality is to make sure that tourist have received the benefits they expect to find in the destination [8]. Benefits received directly influence tourists' decision on their willingness to recommend, say positive thing and revisit Borobudur temple in the future. Considering attracting tourists to performing future behavioral intentions is critically important for the success of destination tourism development.

In order to promote the future behavioral intentions and satisfaction of domestic local tourist, there is an urgent necessity for Borobudur temple authority management should improve on particular service quality aspect. One of them is to provide training programs for the employees and tour guides. The training programs intended to enhance the importance of the aptitude and desire to provide tourists with the best possible service. Hence, the responsiveness is an important service quality dimensions to be recommended when marketing to tourists.

Subsequently this study shows that, cleanliness and well managed of the temple was the important factor that make the tourists feel satisfied with their visitation to Borobudur temple, then, it is very recommended if Borobudur temple authority can work together with the tourists to cooperatively maintain the cleanliness and preserving the Borobudur Temple. Nevertheless, Borobudur Temple Management should be able to arrange and manage the public facilities (i.e. rest room, parking lot and rest area) to be more comfortable used by the tourists.

\section{LIMITATIONS AND FUTURE RESEARCH}

In interpreting the results of this study, one must consider a number of limitations. First, the number of samples that used in this study is limited, which is based on the number of local tourists to Borobudur temple in the first quarter of 2011 (January - March 2011). Second, the study is limited in its general aspects. The questionnaire was only given to individual domestic local tourists who were visiting Borobudur temple at 28-31 May 2012. Future research, may wish to explore the relationship among service quality, tourist satisfaction and future behavioral intentions on the perspective both foreign and domestic local tourists. Another limitation of this study is on its research methods. This study is only focus on interpreting the perceptions of domestic local tourist through quantitative methods. Therefore, its very recommended if the future studies can develop the similar research by combining quantitative and qualitative methods, which then the results can be compared and benchmarked to enrich the academic study of hospitality research in terms of service quality, tourist satisfaction and future behavioral intentions at various tourist destinations. Nevertheless, as a limitation of questionnaire survey, there must be a measurement against error in assessing the respondent's honesty.

\section{ACKNOWLEDGMENT}

The author wish to thank Ms. Nila K. Hidayat, SE, M.M, Swiss German University, for initial knowledge and research direction as well as constant supervision upon completion of this research study.

The author is thankful to the office of National Authority Agency Borobudur UNESCO World Culture Heritage, for their support and cooperation for conducting field research in Borobudur as the largest Buddhist temple in the world. 


\section{REFERENCES}

[1] World Travel and Tourism Council, 2012. Indonesia Travel and Tourism Impact 2012, London: World Travel and Tourism Council.

[2] F. T. Sumacco and S. Richardson, "An Analysis on International Tourist's Perceptions towards Destination Branding: Visit Indonesia 2008 Marketing Campaign," The $2^{\text {nd }}$ International Research Symposium in Service Management, pp. 474-48, 2011.

[3] World Economic Forum, 2011. The Travel and Tourism Competitiveness Report 2011: Beyond The Downturn, Geneva: World Economic Forum.

[4] Ministry of Tourism and Creative Economy of the Republic of Indonesia. (2012). Perkembangan Wisatawan Nusantara (WISNUS). [Online]. http://www.budpar.go.id/budpar/asp/detil.asp?c=111\&id=1191

[5] Ministry of Tourism and Creative Economy of the Republic of Indonesia. (2012). Rekapitulasi Wisatawan Mancanegara Tahun 2007 2011. [Online]. Available: http://www.budpar.go.id/budpar/asp/detil.asp?c=110\&id=1408

[6] Data Pengunjung Candi Borobudur, Prambanan \& Ratu Boko 2008-2011, PT Taman Wisata Candi Borobudur Prambanan \& Ratu Boko, 2011.

[7] J. S. Chen and D. Gursoy, "An Investigation of ourists' Destination Loyalty and Preferences," International Journal of Contemporary Hospitality Management, vol. 13, no. 2, pp. 79-85, 2001.

[8] S. T. Cole, S. J. Crompton, and V. L. Willson, "An Empirical Investigation of the Relationships Between Service Quality, Satisfaction and Behavioral Intentions Among Visitors to a Wildlife Refuge," Journal of Leisure Research, vol. 34, no. 1, pp. 1-24, 2002.

[9] C. Kouthouris and K. Alexandris, "Can Service Quality Predict Customer Satisfaction and Behavioral Intentions in the Sport Tourism Industry? An Application of the SERVQUAL Model in an Outdoors Setting," Journal of Sport Tourism, vol. 10, no. 2, pp. 101-111, 2005.

[10] F. Meng, Y. Tepanon, and M. Uysal, "Measuring Tourist Satisfaction by Attribute and Motivation: The Case of a Nature-based Resort," Journal of Vacation Marketing, vol. 14, no.1, pp. 41, 2008.

[11] M. K. Brady and J. J. Cronin, "Some New Thoughts on Conceptualizing Perceived Service Quality: A Hierarchical Approach," The Journal of Marketing, vol. 65, no. 3, pp. 34-49, 2001.

[12] C. H. Liu and L. C. Yen, "The Effects of Service Quality, Tourism Impact, and Tourist Satisfaction on Tourist Choice of Leisure Farming Types," African Journal of Business Management, vol. 4, no. 8, pp. 1529-1545, 2010.

[13] M. A. O’Neill, P. Williams, M. MacCarthy, and R. Groves, "Diving Into Service Quality - The Dive Tour Operator Perspective," Managing Service Quality, vol. 10, no. 3, pp. 131-140, 2000.

[14] V. A. Zeithaml, A. Parasuraman, and L. L. Berry, Delivering Quality Service: Balancing Customer Perceptions and Expectations, New York: The Free Press, 1990, ch. 2, pp. 20-26.

[15] V. A. Zeithaml, M. J. Bitner, and D. D. Gremler, Services Marketing: Integrating Customer Focus Across the Firm. $5^{\text {th }}$ ed. New York: McGraw-Hill, 2009, ch. 5, pp. 111-116.

[16] G. F. Ross, "Service Quality and Management: The Perceptions of Hospitality Employees," The Journal of Tourism Studies, vol. 4, no. 2, pp. 12-23, 1993.

[17] A. Parasuraman, V. A. Zeithaml, and L. L. Berry, "A Conceptual Model of Service Quality and Its Implication for Future Research," Journal of Marketing, vol. 49, pp. 41-50, 1985.

[18] G. Prayag, "Tourists' Evaluations of Destination Image, Satisfaction, and Future Behavioral Intentions - The Case of Mauritius," Journal of Travel and Tourism Marketing, vol. 26, pp. 836-853, 2009.

[19] E. Atilgan, S. Akinci, and S. Aksoy, "Mapping Service Quality in The Tourism Industry," Managing Service Quality, vol. 13, no. 5, pp. 412-422, 2013.

[20] R. A. Spreng and R. D. Mackoy, "An Empirical Examination of a Model of Perceived Service Quality and Satisfaction," Journal of Retailing, vol. 72, no. 2, pp. 201-214, 1996.

[21] M. Kozak and M. Rimmington, "Tourist Satisfaction with Mallorca, Spain, as an Off-Season Holiday Destination," Journal of Tourism Research, vol. 38, pp. 260-269, 2002.

[22] D. Bowen and J. Clarke, "Reflection on Tourists Satisfaction Research: Past, Present and Future," Journal of Vacation Marketing, vol. 8, no. 4, pp. 297, 2002.
[23] D. A. Baker and J. L. Crompton, "Quality, Satisfaction and Behavioral Intentions," Annals of Tourism Research, vol. 27, no. 3, pp. 785-804, 2000.

[24] S. T. Cole and S. F. Illum, "Examining the Mediating Role of Festival Visitors' Satisfaction in The Relationship Between Service Quality and Behavioral Intentions," Journal of Vacation Marketing, vol. 12, no. 2, pp. 160-173, 2006

[25] S. T. Cole and S. J. Crompton, "A Conceptualization of the Relationships Between Service Quality and Visitor Satisfaction, and Their Links to Destination Selection," Lesiure Studies, vol. 22, pp. 65-80, 2003.

[26] A. J. Kvist and B. Klefsjö, "Which Service Quality Dimensions are Important in Inbound Tourism?" Managing Service Quality, vol. 16, no. 5 , pp. 520-537, 2006

[27] P. Kotler and G. Armstrong, Principles of Marketing, $13^{\text {th }}$ ed. Upper Saddle River, New Jersey: Pearson Education Inc, 2010, ch. 1, pp. 13-16.

[28] W. Jankingthong and P. Gonejarat, "The relationships of Factors Affecting Post-purchase Behavioral Intentions in Tourism Sector," Silpakorn University Journal of Science, Humanities and Arts, vol. 12, no.1, pp. 72-90, 2012.

[29] J. S. Chen and D. Gursoy, "An Investigation of ourists' Destination Loyalty and Preferences," International Journal of Contemporary Hospitality Management, vol. 13, no. 2, pp. 79-85, 2001.

[30] S. M. Meng, G. S. Liang, and S. H. Yang, "The Relationships of Cruise Image, Perceived Value, Satisfaction, and Post-purchase Behavioral Intention on Taiwanese Tourists," African Journal of Business Management, vol. 5, no. 1, pp. 19-29, 2011

[31] Y. Yoon and M. Uysal, "An Examination of the Effects of Motivation and Satisfaction on Destination Loyalty: A Structural Model," Tourism Management, vol. 26, pp. 45-56, 2005.

[32] R. L. Oliver, "Whence consumer loyalty?" Journal of Marketing, vol. 63, pp. 33-44, 1999.

[33] M. Blut, H. Evanschitzky, V. Vogel, and D. Ahlert, D, "Switching barriers in the four-stage loyalty model," Advances in Consumer Research, vol. 34, pp. 726-734, 2007.

[34] J. E. Bigné, A. S. Mattila, and L. Andreu, "The Impact of Experiential Consumption Cognitions and Emotions on Behavioral Intentions," Journal of Service Marketing, vol. 22, no. 4, pp. 303-315, 2008.

[35] S. Lee, S. Jeon, and D. Kim, "The Impact of Tour Quality and Tourist Satisfaction on Tourist Loyalty: The Case of Chinese Tourist in Korea," Tourism Management, vol. 32, pp. 1115-1124, 2011.

[36] U. Sekaran and R. Bougie, Research Methods for Business: A Skill Building Approach. $5^{\text {th }}$ ed. West Sussex: John Wiley \& Sons, Inc, 2009, ch. 7, pp. 158-165.

[37] J. F. Hair, W. C. Black, B. J. Babin, and R. E. Anderson, Multivariate Data Analysis, $7^{\text {th }}$ ed. New Jersey: Pearson Education Inc, 2010, ch. 3 , pp. 116-117.

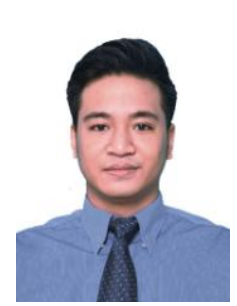

Ivyanno U. Canny was born in Jakarta, $7^{\text {th }}$ April 1990. He received his Bachelor's degree (2012) in Business Administration from Swiss German University, Schools of Business Administration, with international network link to University of Applied Sciences South-Westphalia, Soest, Germany. In 2011, he attend winter school program in Business Administration with informatics at Fachhochschule Sudwestfalen, South - Westphalia, Soest, Germany. His research interests include consumer behavior, strategic marketing, service management and hospitality management.

He has worked for MEA Brand Building GmbH, Berlin - Germany as a marketing and creative team officer for world's top luxury fashion brands, such as Escada, Hugo Boss and OMEGA in 2011. He also has experienced as a marketing and sales administration in PT TUV Rheinland Indonesia - the German Certification body, TÜV Rheinland Group Germany in 2009.

Ivyanno U. Canny has joined and becoming a member of International Economics Development Research Center (IEDRC). He has published an international proceeding paper in the $3^{\text {rd }}$ International Conference on Business, Economics and Tourism Management (CBETM 2012) in Hong Kong, 2012. 